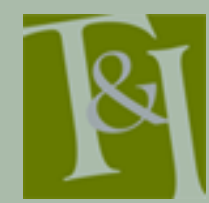

The International Journal for Translation \& Interpreting Research

trans-int.org

\title{
Translation and negotiation of linguistic varieties amongst translators of the Bosnian, Croatian and Serbian languages
}

\author{
Jim Hlavac \\ Monash University \\ Jim.Hlavac@monash.edu
}

DOI: ti.105202.2013.a06

\begin{abstract}
This paper examines the situation of twenty-eight Australia- and Europebased translators for the Bosnian, Croatian and Serbian languages and presents responses on the number of accreditations they hold and how they negotiate requests for assignments in languages other than their 'own'. Specifically, data is gathered on the following: accepting or declining assignments for languages in which a translator does not have accreditation; responses to requests where the nominated language has an unofficial designation; increased income as an incentive for work in more than one language and use of resources across languages. Two widely-held outlooks on working in other languages emerge: the first outlook views the languages as distinct and separate and encompasses those informants who hold one accreditation and who work almost exclusively in one language only; the other widely-held outlook recognises the separateness of the languages and advocates multiple accreditation as a means to perform translation across two or more languages.
\end{abstract}

Keywords: translation practices, translation role-relationships, closely-related languages, Bosnian, Croatian, Serbian.

\section{Introduction}

Translators are often assumed to be native speakers and insiders (in an ethnocultural sense) of at least one of the languages that they work in, notwithstanding their own desires or the demands of the Translation and Interpreting (hereafter: T\&I) labour market for them to be able to work in third and subsequent languages. For many T\&I trainees or practitioners the addition of or maintenance of another language to their list of language combinations is a substantial time and resource commitment. For this reason, T\&I trainees or practitioners usually only consider adding another language to their repertoire that is cognate with one of their existing languages. For some practitioners, the addition of another language may not need to be so laborious where there are other languages that are similar to their existing ones. For instance, T\&I practitioners that already work in Spanish sometimes consider adding Portuguese; those working in Finnish may augment their services with Estonian; practitioners with Turkish may broaden their inventory to include Azeri and Kazakh and so on. There are clusters of languages that are so closely related that even naïve speakers or readers are able to understand the speech or text of speakers of other languages within the same cluster: Bahasa Indonesia and Malay, Laotian and Thai, Moldovan and Romanian are examples of mutually intelligible languages. This paper examines practices of translators from another language cluster, that of the Bosnian, Croatian and Serbian languages, that bear a very high degree of mutual intelligibility to each other, but which were 'divided' by the 1990s collapse of the Socialist Federal Republic of Yugoslavia (hereafter: SFRY). 
Divisions between the three languages were heightened by armed conflicts between speakers of each of the languages and by the legacy of ethnic homogenisation that is now recognisable in the respective homelands of the languages as well as outside the homelands where émigré communities now reside.

This paper provides a description of a sample of twenty-eight translators working in one, two or all three of these languages, who are mostly based in Australia. This paper commences with a brief discussion on the status and recent re-standardisations of Bosnian, Croatian and Serbian and on previous designations for the languages of Bosniaks, Croats, Serbs and Montenegrins. The relevance of recent changes in each of these languages to T\&I is presented to contextualise the situation and codes that translators now work in. Demographic information about translators for Bosnian, Croatian and Serbian includes: country of birth, countries resided in, declarations of nativespeaker or near native-speaker proficiency, credentials held (for which language/s) and length of time working as a translator. In the Australian context, a credential refers to accreditation ${ }^{1}$ awarded by the National Accreditation Authority for Translators and Interpreters (hereafter: NAATI); in Europe, a credential refers to a university qualification and/or certification gained for specialist T\&I work (see below section 4). The paper then investigates if and how translators negotiate (that is, accept or decline) requests and translation assignments in their 'own' language, and more interestingly, in other languages, and whether this happens unintentionally and accidentally or according to particular strategies that show how translators conceptualise their language/s and their roles towards specific language communities. To this end, this paper seeks to test the following hypothesis: translators with a credential in two or more languages are more likely to accept 'generic language requests' and requests for assignments using 'unofficial designations' than translators with a credential in one language only.

Quantitative data elicited from questionnaires completed anonymously by twenty-eight translators is used as the basis for discussion. This data is augmented by comments elicited and provided by informants to show not only informants' experiences but their affective and personal reactions to real and hypothetical situations.

\section{Language policy in the SFRY: official and popular designations of Bosnian, Croatian, Serbian and Montenegrin.}

Until 1991, the SFRY listed three official national languages: Serbo-Croatian, Slovenian and Macedonian, and recognised the status of the languages of other nationalities such as Albanian, Hungarian, Italian etc. The term 'Yugoslav' was used by some locals abroad for the 'sake of simplicity' when in contact with foreigners, and by foreigners who presumed the name of the language to be coterminous with the name of the country. The term 'our language' was also a common euphemism that avoided the official term 'Serbo-Croatian', particularly as it disenfranchised two constituent peoples: Bosniaks and Montenegrins.

A detailed description of the designations of the languages of the Bosniaks, Croats, Montenegrins and Serbs goes beyond the bounds of this paper. The interested reader is referred to the many texts that deal with the creation (based originally on romanticism and pan-Slavicism and later on socio-political unitarism and Yugoslav federalism) and dissolution (based on preferences for ethnicity and language designation to be coterminous) of 
linguistic hypernyms that attempted to encompass the languages of these four peoples (e.g. Bugarski, 2002; Okuka, 1998; Neweklowsky, 2003; Bugarski \& Hawkesworth, 2004; Greenberg, 2004a; Badurina, Pranjković \& Silić, 2009; Maštrović \& Machala, 2011).

Although Bosnian had some currency as a designation of the language of some of the inhabitants of Bosnia, its emergence as the official designation of the language of the Bosniaks did not occur until the 1991 census and the official declaration by Bosnian and Herzegovinian Muslims that their selfdeclared ethnicity would from then on be Bosniak and their language Bosnian. Until democratic, multi-party elections in 1990, the official designations for the languages of all people living in Bosnia-Herzegovina (regardless of whether they were Muslim², Croat or Serb) were Serbocroatian and Croatoserbian. These terms did not, in their form, include the single most numerous ethnic group of Bosnia-Herzegovina, the (Muslim) Bosniaks. The Bosniaks' decision to officially call their language Bosnian was founded on this term as a long-standing one that enjoyed widespread (but usually unofficial) use (Halilović, 1998), while dissatisfaction with a composite term (Serbocroatian or Croatoserbian) that did not include the name of this national group was only a secondary motivation for change (Jahić, 2000). In regard to Bosnia-Herzegovina, it is important to note, as Table 1 below shows, that only a relative majority of the inhabitants of Bosnia-Herzegovina identify their language as Bosnian (cf. Tolimir-Hölzl, 2009), while a combined larger number use the terms Serbian or Croatian.

Croats are dispersed over a wide area but generally hold to their own vernacular and also to the term 'Croatian'. Until its secession from SFRY, the official designation in Croatia was Croatian literary language also known as Croatian or Serbian (see below Table 1), a cumbersome term that was a compromise between the Yugoslav Communist Party's preference for SerboCroatian and Croatian linguists' advocacy of the formulation Croatian literary language (Babić, 1990). After democratic elections in 1990, the term Croatian literary language became the official designation. Today, Croatian is the preferred name that all Croats in Croatia and Bosnia-Herzegovina and most Croats in Serbia and Montenegro employ to refer to their own language (cf. Kalogjera, 2004).

In Serbia, and amongst Serbs generally who made up the largest single national group in SFRY, Serbian existed alongside Serbo-Croatian as the label commonly used. Amongst all national groups in SFRY, the term SerboCroatian was probably most popular in Serbia (Radovanović, 2004). It was a popular label as within this label, Serbs recognised a continuation of their vernacular and literary standard which was not compromised or threatened by the vernaculars or standards of other national groups. However, Serbian remained the colloquial and still widely-used term in Serbia and amongst the large Serb populations in Bosnia-Herzegovina and Croatia. After 1991, Serbian replaced Serbo-Croatian as the official label for the national language of Serbia, within the Bosnian-Serb entity in Bosnia-Herzegovina and amongst the Serbian minority in Croatia. After 1991 Cyrillic was reinstated as the primary, officially favoured alphabet (Popović, 2004), after its use had been in decline in the 1970s and 1980s.

In Montenegro, due to the majority population's shared Orthodox faith with Serbia, national and linguistic designations have traditionally been closely aligned to those in Serbia and this resulted in self-perceptions of Montenegrins as a branch of the Serbian people (cf. Greenberg, 2004b; Nikčević 2009). The development of a codified standard, under the name of Montenegrin is of recent vintage with the first orthography released in 2009 and the first grammar published in 2010. Due to the small number of speakers 
of Montenegrin and an absence of informants born or raised in Montenegro (see below Tables 2-4) Montenegrin is, apart from one hypothetical scenario (see below Tables 13 and 14), not further examined in this paper.

In terms of mutual intelligibility, the difference or gap between one language variety and another is referred to by the German term Abstand (Kloss, 1976). There are nowadays many noteworthy differences between the Bosnian, Croatian, Serbian and Montenegrin standard languages but the number of similarities means that this criterion alone does not render them Abstandsprachen (languages between which there is a clear and major natural separation). At the same time, the development of four distinct and fullyfledged standards allows each of the languages concerned to be now considered effectively separate, since they are used independently of other, neighbouring standards - i.e., all four can be classed as Ausbausprachen, or languages for which separate status has been cultivated (Kloss, 1976). Recent advances in the study of corpus planning also include sociolinguistic and ethno-political features: views of speakers towards their language(s); notions of ownership and gatekeeping; ethnic, geographic or religious distinctions amongst groups; linguistic rights and declarations of 'language status' as a means to emancipate disenfranchised or subjugated groups (Pupavac, 2006). By these parameters as well, the author considers these four distinct and separate languages. Table 1 below recounts the designations used before and after 1991.

\begin{tabular}{lllll}
\hline & $\begin{array}{l}\text { Bosnia- } \\
\text { Herzegovina }\end{array}$ & Croatia & Serbia & Montenegro \\
\hline $\begin{array}{l}\text { Official } \\
\text { pre-1991 } \\
\text { designation }\end{array}$ & $\begin{array}{l}\text { 'Serbocroatian' } \\
\text { 'Croatoserbian' }\end{array}$ & $\begin{array}{l}\text { 'Croatian } \\
\text { literary } \\
\text { language also } \\
\text { known as } \\
\text { Croatian or }\end{array}$ & $\begin{array}{l}\text { 'Serbo- } \\
\text { Croatian' }\end{array}$ & 'Serbo-Croatian' \\
& & & \\
& & Serbian' & & \\
\hline $\begin{array}{l}\text { Current } \\
\text { official } \\
\text { design- } \\
\text { nations of } \\
\text { language/s }\end{array}$ & 'Cosnian', & 'Croatian' & 'Serbian' & 'Montenegrin' + \\
\hline
\end{tabular}

Table 1: Previous and current designations of official languages in four successor states of SFRY.

Table 1 above shows pre-1991 and current designations of the official language(s) of the four countries. Throughout Bosnia-Herzegovina (in both entities - the Bosniak-Croat Federation and in Republika Srpska - and in the neutral Brčko District), all three languages have official status (Palić, 2009). In practice, the language designation and the official standard used reflects the majority population of that area. In the Bosnian-Serb entity (Republika Srpska) Serbian is the dominant language and the Cyrillic alphabet is the officially preferred script. The language of instruction in schools, the language of print and electronic media and the language used in official communication by the Bosnian Serb administration is Serbian. (The variety of Serbian used in the Republika Srpska is steadily converging towards the official standard of neighbouring Serbia as Serbian ekavian pronunciation now becomes increasingly accepted and even promoted, cf. Dragosavljevic 2000). Although they also enjoy co-official status in the Bosnian Serb entity, the use of Bosnian and Croatian is tacitly discouraged and their use restricted to speakers' home or private domains (Tolimir-Hölzl, 2009). These languages 
are also portrayed as the languages of 'outsiders' who reside elsewhere - in the Bosniak-Croat Federation or in Croatia. In the Bosniak-Croat Federation, the majority population of each area determines the language employed in public use. In majority Bosniak areas this is Bosnian; in majority Croat areas it is Croatian. In ethnically mixed areas of northern Hercegovina, central and northern Bosnia, both languages enjoy an equal but separate status to one another; there are separate Bosnian-language and Croatian-language schools (Gustavsson, 2009), separate newspapers, radio stations, television channels etc. In the Bosniak-Croat Federation, Serbian occupies only a peripheral status.

Croatia and Serbia are not mono-ethnic states, but in both countries, the dominant ethnic group overwhelmingly favours a linguistic designation that is coterminous with its nationality. In addition to Croatian being the official language in Croatia, the official alphabet is the Roman-script alphabet, while in Serbia, the official language is Serbian and the official alphabet Cyrillic.

In Montenegro, the constitution states that ' $[t]$ he official language is Montenegrin. The Roman-script and Cyrillic alphabets enjoy equal status. The Serbian, Bosnian, Albanian and Croatian languages also enjoy official status' (Constitution of Montenegro 2007, p. 4). The formulation contained in the Montenegrin constitution appears as a 'textbook' example of a broad and inclusive language planning policy (Glušica, 2009) that was devised as a compromise form to not disenfranchise any group.

In addition to the re-standardisation and re-naming of the official languages, what is also of interest to T\&I practitioners are the conventions relating to language planning in the successor states of SFRY. Language planning refers to the function and status that a particular variety has in a particular locality, area or country. In the case of Bosnian, Croatian, Montenegrin and Serbian, this means that while each respective language is the official language in one country (in the case of Bosnia-Herzegovina there are three - Bosnian, Croatian and Serbian; in the case of Montenegro there are one plus four), the status of other languages is regulated according to the status of minorities domiciled in each country and their desire to name their language accordingly. Thus, while Croatian is the official language of Croatia, in those areas of Croatia where the Serbian minority has official status, the use of the Serbian language is also regulated by statute alongside that of Croatian. A similar situation applies in Serbia in regard to the official status of Serbian, but also Bosnian, Croatian and Montenegrin in those areas of Serbia where these minorities are domiciled. Language planning in all four successor states of SFRY regulates the four languages as separate languages.

\section{Language policies and designations: implications for $T \& I$ practitioners}

There are now four declared and separately codified language standards and the implications of this on T\&I in the respective countries themselves vary. Due to the similarity between the four languages, translation between these languages hardly ever occurs. In the 1990s, Croatian state television trialled the use of Croatian sub-titles for Serbian films with actors speaking Serbian but this met with a mixed response and was abandoned (cf. Kuhiwczak, 1999). There are some areas where one language is not readily comprehensive to speakers of the other, e.g. scientific and specialist technical texts in Croatian or Serbian need to be closely edited if they are to be presented to audiences from the other language, chiefly due to the lexical and semantic differences between the two languages. What has changed is that 
Serbian texts in Cyrillic need to be transliterated into Roman-script Croatian or Bosnian for readerships that lack Cyrillic-script literacy skills in Croatia or Bosnia-Herzegovina. Prior to 1991 electronic and print media presented source texts or quotes in the original language without alteration, i.e. quotes from Serbian speakers were represented verbatim in the Croatian press; Bosnian text remained unchanged when published in Montenegro. In most of the successor states, public and privately owned media now represent text or quotes from any other language in a translated form. The interventions that media make are chiefly lexical and sometimes changes in register or syntax. Lexical and phraseological changes that editors make can be examples of 'transposition', 'modulation', 'correspondence' or 'adaptation' (Vinay \& Darbelnet, 1958/1972, p.55 as cited and translated in Pym, 2010, p.13).

Under the official designation of 'Serbo-Croatian' it was common in SFRY for translations and interpretations to be provided in Serbian for Bosnian, Croatian and Montenegrin audiences. The reverse was much less common. Now, product advertisements and marketing of foreign goods and services follow national guidelines, not so much out of fear of legal sanctions but out of fear that these will meet with negative reactions from potential markets. The situation on the ground has changed in all SFRY successor states so that practitioners can no longer employ their own language variety within the designation of 'Serbo-Croatian'. Instead, practitioners employ (usually) their own, national variety (that which is almost always coterminous with their ethnicity and country of residence) and work with it only or, if they wish to seek work in other languages from former SFRY, they are required to acquire proficiency in the standards of these other languages. The large number of practitioners who offer their services for two or three languages on open directories or who list multiple working languages in their professional profiles invite investigation on how they view their abilities and how they interact with the marketplace and clients.

\subsection{Distinct codified standards and homogenised populations: implications for $\mathbf{T} \& \mathbf{I}$}

Today, any T\&I practitioner working in any of the four languages (Bosnian, Croatian, Montenegrin or Serbian) must have proficiency in the respective national standard language. This is unremarkable and mirrors the situation of translators in other countries. However, if a translator wishes to work outside his or her 'own' language, the question arises as to what level of proficiency a T\&I practitioner must demonstrate in order to accept and perform assignments competently. If that proficiency is passive, does that allow a translator to only translate from that language but not into it? Or can T\&I practitioners with only passive skills also translate into that language with whichever successful or unsuccessful attempts at accommodating to it its standard, and believe that they have performed a competent translation? Can a translator accept work for a language, use another language's standard, and believe that this is acceptable to his or her audience and by professional standards? Who wields power in T\&I interactions - the translator whose services a client requires, or the client who secures the translator's employment? These are questions that this paper seeks to address by eliciting responses from informants about their readiness to work across languages, self-diagnoses of their language proficiencies and (habitual or impromptu) strategies to linguistically accommodate to other parties. 


\subsection{A cross-national overview of translator training and translation services for the Bosnian, Croatian and Serbian languages.}

In Bosnia-Herzegovina (University of Sarajevo), Croatia (University of Zagreb) and Serbia (University of Belgrade) most T\&I training occurs in university language departments, as part of under-graduate translation streams in the remodelled three-year bachelor degree programs. An MA conference interpreting degree has been offered at the University of Zagreb since 2005, but no equivalent post-graduate exists in Croatia for translation. At the University of Sarajevo, a post-graduate T\&I stream is offered for languages such as English, German and French in combination with the three official languages of Bosnia-Herzegovina: Bosnian, Croatian and Serbian. In Serbia, the Association of Scientific and Technical Translators of Serbia offers 12-month courses in T\&I in five languages for graduates with a Bachelor degree. Overall, in these three countries, training exists only for a small number of other European languages, and trainees graduate with a philological degree, rather than a specifically T\&I one. Most translators in the three countries require no further training to work in the field. The T\&I sector in all three countries is generally unregulated; many practitioners are graduates of university programs but many others lack formal training or testing of their skills. Professional associations exist which also function as service points for T\&I services such as the Association of Translators and Translators of Bosnia-Herzegovina, the Croatian Association of Scientific and Technical Translators and the Association of Scientific and Technical Translators of Serbia.

Outside the homeland countries, there are some T\&I training centres as well as many T\&I service providers for these languages in Western Europe and in the New World, due to the number of political and economic migrants, guest workers and war refugees that have left the source countries in large numbers over the last 50 years. Discussion here will focus on T\&I training institutions that offer any of the languages, designations used by institutions and official authorities and general provision of T\&I services.

Austria and Germany are the countries closest to the former SFRY which have sizeable numbers of speakers of all three languages. Austria has two universities, Vienna and Graz Universities, with T\&I undergraduate and postgraduate programs in 'Bosnian-Croatian-Serbian' and this is also the designation used in language learning programs at these same universities (Neweklowsky, 2004). Austria has a semi-official policy of 'B-C-S' in educational settings, but the professional association, Universitas, through its online directory, categorises the three languages separately (Universitas, n.d.). No German university offers T\&I training in any of the three languages, but the German Bundesverband der Dolmetscher und Übersetzer (Federal Association of Interpreters and Translators) offers all three languages separately (as well as the designation 'Serbo-Croatian' in its online directory (BDÜ 2012). Examining bodies for T\&I credentialing exist for court interpreters and translators at the federal state level in Germany which also distinguish between the four languages - Bosnian, Croatian, Montenegrin, Serbian - and which do not use the term 'Serbo-Croatian' (Justizportal des Bundes und der Länder, n.d.)

In the UK, the Institute of Linguists offers testing in the Diploma of Translation in Croatian and Serbian as separate languages and the National Register of Public Service Interpreters includes all three languages separately without the term 'Serbo-Croatian' (NRPSI, 2011, 2004). In Canada, the Association of Interpreters and Translators in Ontario offers testing in Croatian, Serbian and Serbo-Croatian as three separate languages (ATIO, n.d.). In British Columbia, all three languages are offered separately. On the 
ground the provincial professional bodies with online directories offer Croatian and Serbian as separate languages, while Bosnian is largely absent. In the USA, the ATA introduced translation tests for Croatian in 2005 and undertook to introduce separate tests for Bosnian and Serbian in the near future (ATA, 2012).

In Australia, Croatian and Serbian were officially recognised as separate and distinct languages in the early 1980s due to lobbying from both ethnic/community groups for official designations to reflect their own designations. University language programs (e.g. Macquarie University) reflect these distinctions and the national accreditation/credentialing body, NAATI, listed Croatian and Serbian as separate languages and later added Bosnian to its list of 65 languages in the mid-1990s (NAATI, 2011a). All official and almost all private T\&I work is translated into or from the three languages - the terms 'Serbo-Croatian', 'Bosnian-Croatian-Serbian' or 'Yugoslav' are barely used in Australia.

The United Nations does not have a stated policy of 'recognised' languages, and instead accepts the designations that its member states prescribe. One UN institution has adopted a policy of grouping Bosnian, Croatian and Serbian together - the International Criminal Tribunal for the former Yugoslavia (ICTY) in The Hague, although the former Head of Interpretation Unit at the ICTY mentions that 'this designation does not in any way intend to put the three languages under the same hat or claim that they are one and the same. ... The choice was guided by pragmatic reasons...' (Draženović-Carrieri, 2002, p.49; cf. Schweda Nicholson, 2003). The formulation that the ICTY uses is that the language that a defendant or a witness will receive translations or interpretation in will not necessarily be his or her native language, '...but a language that he understands' (DraženovićCarrieri, 2002, p.49). In a decision on a request from a defendant to receive translated transcripts and interpretation in 'a language which he understands', the pre-trial judge 'denied the Accused's request to receive all relevant documents 'in [the] Serbian [language and written] in Cyrillic [script]', determining that the right of an accused to receive relevant material in a language he understands does not entail 'a right for an accused ... to come before this Tribunal and demand the production of documents in any language ... he chooses" (ICTY, 2010. Original single quotation marks and ellipsis. Square brackets mine.). Scarcity of resources and time restrictions are also listed as reasons why the request was rejected (cf. Dragovic-Drouet, 2007). The policy of the ICTY suggests that it expects defendants and witnesses to accommodate to linguistic varieties that may not be 'their own' but which are intelligible, at least in a passive sense (cf. Myers-Scotton, 1983; Giles, Coupland \& Coupland, 1991; for models of linguistic accommodation).

Overall, in the successor states of SFRY and in countries with significant migrant populations from these countries, the distinctness of each language is upheld through separate designations. In other countries, there are separate designations as well as joint or compound ones. It may be that joint or compound ones are employed for cost-saving reasons.

\section{Methodology}

Invitations to participate in this research on translators were sent firstly to Bosnian, Croatian and Serbian translators who advertise their services on the AUSIT [Australian Institute for Interpreters and Translators] website and on the NAATI online directories ${ }^{3}$. Two agencies and two health services with a 
large number of Bosnian-, Croatian- and Serbian-speaking clients were contacted in Australia. Lastly, a Croatian translator colleague in Austria distributed the link to her contacts across Europe (Croatia, Germany, Serbia) who hold academic degrees in philology (foreign languages) that usually included translation subjects as a definable stream in under-graduate foreign language instruction programs in former SFRY. The sample of informants consists of nineteen translators who reside in Australia, six in Croatia, two in Serbia and one in Germany. Although electronic communication enables international and asynchronous interchange between translation providers and users, it is likely that informants' practices are, at least partly, influenced by the local or national practices of the country they reside in. The response rate from contacted potential informants (twenty-right out of approx. eighty $\approx 35$

$\%)$ is reasonably high. However, the sample cannot be considered representative of translators of these three languages in Australia or to be representative of translators of these three languages in general.

Potential informants were sent an anonymous questionnaire containing twenty-five questions at a Survey Monkey site. Informants were sent the invitation email and the explanatory statement in both English and their other language, Bosnian, Croatian or Serbian. Sixteen informants filled out the questionnaire in English, eight in Croatian, one in Bosnian and three in Serbian. Comments made by informants in languages other than English have been translated into English by the author. Questionnaires were collected from informants from July to September 2010.

Questions pertaining to informants' ethnicity were not asked, nor age. Language proficiency and even assumptions of being a 'native-speaker' are not necessarily coterminous with ethnicity; some translators work in languages whose 'ethnicities' they may not belong to. Most translators acknowledge that cultural knowledge rather than shared ethnicity is a key attribute of translation work and many translators from Bosnia-Herzegovina, Croatia and Serbia may decline mono-terminous self-definitions. Informants' countries of birth were elicited, but not the town or area that they originate from. There is generally greater cross-linguistic similarity between speakers who originate from areas that are adjacent to each other e.g. speakers from the Dalmatian hinterland in Croatia and western Herzegovina; speakers in Croatian western Srijem and Serbian eastern Srem. As informants' place of origin was not elicited, the influence of cross-national similarities due to certain shared regional language varieties cannot be further explored as a factor to account for informants' responses.

The terms 'native speaker' and 'near-native speaker' are used as commonly accepted yardsticks of 'complete' proficiency and 'near-complete' proficiency in a language (cf. Love \& Umberto, 2010). Informants were free to interpret these terms to apply to their chronologically first-learnt language/s, the language/s that they feel most 'dominant' in, and/or the language/s of the ethnic group/s that they belong to. The term 'near-native speaker' refers to languages that informants report having high level proficiency in, sufficiently high for informants to employ these languages in their work. All Australia-based translators have NAATI bi-directional (into and from English) accreditation. The translator in Germany has NAATI unidirectional (into English) accreditation. The other translators based in Croatia and Serbia are holders of philological degrees with a T\&I component (see above 3.2). The Europe-based informants were left to select which languages they work in (from and into) which always reflected the country in which they completed their philological degree and in which they currently reside or previously resided. Thus, Europe-based translators who selected one language in which they work, have been allocated to the 'single accreditation' 


\begin{tabular}{|c|c|c|c|c|c|c|c|}
\hline No. & $\begin{array}{l}\text { Country of } \\
\text { birth }\end{array}$ & $\begin{array}{l}\text { Countries } \\
\text { resided in }\end{array}$ & $\begin{array}{l}\text { Native speaker } \\
\text { of }\end{array}$ & $\begin{array}{l}\text { Near-native } \\
\text { speaker of }\end{array}$ & $\begin{array}{l}\text { Accreditation } \\
\text { from \& into }\end{array}$ & $\begin{array}{l}\text { Age at arrival } \\
\text { in Aust. }\end{array}$ & $\begin{array}{l}\text { Length of } \\
\text { time } \\
\text { worked as } \\
\text { trsltr. }\end{array}$ \\
\hline 1 & USA & USA, Croatia & English & Croatian & $\begin{array}{l}\text { Croatian, } \\
\text { English }\end{array}$ & $\begin{array}{l}21 \text { (returned } \\
\text { to Croatia) }\end{array}$ & 18 years \\
\hline 2 & Australia & $\begin{array}{l}\text { Australia, } \\
\text { Scotland, } \\
\text { Germany }\end{array}$ & English & German & $\begin{array}{l}\text { Croatian (from } \\
\text { only) English, } \\
\text { German }\end{array}$ & Born in Aust & 19 years \\
\hline 3 & Croatia & $\begin{array}{l}\text { Croatia, } \\
\text { Australia }\end{array}$ & Croatian & English & $\begin{array}{l}\text { Croatian, } \\
\text { English }\end{array}$ & 11 & 15 years \\
\hline 4 & $\begin{array}{l}\text { Bosnia- } \\
\text { Herzegovina }\end{array}$ & $\begin{array}{l}\text { Bosnia- } \\
\text { Herzegovina, } \\
\text { Australia }\end{array}$ & Bosnian & $\begin{array}{l}\text { Croatian, } \\
\text { Serbian, } \\
\text { English }\end{array}$ & $\begin{array}{l}\text { Bosnian, } \\
\text { English }\end{array}$ & 21 & 10 \\
\hline 5 & $\begin{array}{l}\text { Bosnia- } \\
\text { Herzegovina }\end{array}$ & $\begin{array}{l}\text { Bosnia- } \\
\text { Herzegovina, } \\
\text { Australia }\end{array}$ & $\begin{array}{l}\text { Bosnian, } \\
\text { Croatian, } \\
\text { Serbian } \\
\end{array}$ & English & $\begin{array}{l}\text { Bosnian, } \\
\text { English }\end{array}$ & 37 & 5 years \\
\hline 6 & Macedonia & $\begin{array}{l}\text { Macedonia, } \\
\text { Serbia, } \\
\text { Australia }\end{array}$ & Macedonian & $\begin{array}{l}\text { Bosnian, } \\
\text { Croatian, } \\
\text { Serbian, } \\
\text { English }\end{array}$ & $\begin{array}{l}\text { Serbian, } \\
\text { English, } \\
\text { Macedonian }\end{array}$ & 33 & 24 years \\
\hline 7 & Serbia & $\begin{array}{l}\text { Serbia, } \\
\text { Australia }\end{array}$ & Serbian & $\begin{array}{l}\text { Bosnian, } \\
\text { Croatian, } \\
\text { English }\end{array}$ & Serbian, English & 28 & 2 years \\
\hline 8 & Croatia & $\begin{array}{l}\text { Croatia, } \\
\text { Australia }\end{array}$ & Croatian & English & $\begin{array}{l}\text { Croatian, } \\
\text { English }\end{array}$ & 25 & 20 years \\
\hline 9 & Macedonia & $\begin{array}{l}\text { Macedonia, } \\
\text { Australia }\end{array}$ & Macedonian & $\begin{array}{l}\text { Serbian, } \\
\text { English }\end{array}$ & $\begin{array}{l}\text { Serbian, } \\
\text { English, } \\
\text { Macedonian }\end{array}$ & 13 & 26 years \\
\hline 10 & Serbia & $\begin{array}{l}\text { Serbia, } \\
\text { Australia }\end{array}$ & Serbian & English & Serbian, English & 13 & 25 years \\
\hline 11 & Serbia & $\begin{array}{l}\text { Serbia, } \\
\text { Australia }\end{array}$ & Serbian & English & Serbian, English & 25 & 25 years \\
\hline 12 & Croatia & $\begin{array}{l}\text { Croatia, } \\
\text { Australia } \\
\end{array}$ & Croatian & English & $\begin{array}{l}\text { Croatian, } \\
\text { English }\end{array}$ & 27 & 33 years \\
\hline 13 & Australia & Australia & $\begin{array}{l}\text { Bosnian, } \\
\text { English }\end{array}$ & $\begin{array}{l}\text { Croatian, } \\
\text { Serbian }\end{array}$ & $\begin{array}{l}\text { Bosnian, } \\
\text { English }\end{array}$ & Born in Aust & 15 years \\
\hline 14 & Serbia & $\begin{array}{l}\text { Serbia, } \\
\text { Morocco, } \\
\text { France } \\
\end{array}$ & $\begin{array}{l}\text { Serbian, } \\
\text { French }\end{array}$ & & Serbian, English & $\begin{array}{l}\text { Returned to } \\
\text { Serbia }\end{array}$ & 15 years \\
\hline 15 & USA & USA, Serbia & $\begin{array}{l}\text { Serbian, } \\
\text { English }\end{array}$ & & Serbian, English & $\begin{array}{l}\text { Returned to } \\
\text { Serbia }\end{array}$ & 15 years \\
\hline 16 & Croatia & Croatia & Croatian & $\begin{array}{l}\text { English, } \\
\text { German }\end{array}$ & $\begin{array}{l}\text { Croatian, } \\
\text { English }\end{array}$ & $\begin{array}{l}\text { Remains in } \\
\text { Croatia }\end{array}$ & 5 years \\
\hline 17 & Croatia & $\begin{array}{l}\text { Croatia, } \\
\text { Germany, } \\
\text { Switzerland }\end{array}$ & $\begin{array}{l}\text { Croatian, } \\
\text { English, } \\
\text { German } \\
\end{array}$ & & $\begin{array}{l}\text { Croatian, } \\
\text { German, } \\
\text { English } \\
\end{array}$ & $\begin{array}{l}\text { Returned to } \\
\text { Croatia }\end{array}$ & 25 years \\
\hline
\end{tabular}

Table 2. Demographic features of informants with one accreditation 


\begin{tabular}{|c|c|c|c|c|c|c|c|}
\hline No. & $\begin{array}{l}\text { Country of } \\
\text { birth }\end{array}$ & $\begin{array}{l}\text { Countries resided } \\
\text { in }\end{array}$ & $\begin{array}{l}\text { Native speaker } \\
\text { of }\end{array}$ & $\begin{array}{l}\text { Near-native } \\
\text { speaker of }\end{array}$ & $\begin{array}{l}\text { Accreditation } \\
\text { from \& into }\end{array}$ & $\begin{array}{l}\text { Age at } \\
\text { arrival in } \\
\text { Aust. }\end{array}$ & $\begin{array}{l}\text { Length } \\
\text { of time } \\
\text { worked } \\
\text { as trsltr. }\end{array}$ \\
\hline 18 & $\begin{array}{l}\text { Bosnia- } \\
\text { Herzegovina }\end{array}$ & $\begin{array}{l}\text { Bosnia- } \\
\text { Herzegovina, } \\
\text { Serbia, Australia }\end{array}$ & $\begin{array}{l}\text { Bosnian, } \\
\text { Serbian }\end{array}$ & $\begin{array}{l}\text { Croatian, } \\
\text { English }\end{array}$ & $\begin{array}{l}\text { Croatian, } \\
\text { Serbian, } \\
\text { English } \\
\end{array}$ & 31 & 34 years \\
\hline 19 & $\begin{array}{l}\text { Bosnia- } \\
\text { Herzegovina }\end{array}$ & Serbia, Australia & Serbian & $\begin{array}{l}\text { Bosnian, } \\
\text { English }\end{array}$ & $\begin{array}{l}\text { Bosnian, } \\
\text { Serbian, } \\
\text { English } \\
\end{array}$ & 28 & 14 years \\
\hline 20 & Croatia & Croatia, Australia & Croatian & $\begin{array}{l}\text { Bosnian, } \\
\text { Serbian, } \\
\text { English } \\
\end{array}$ & $\begin{array}{l}\text { Bosnian, } \\
\text { Croatian, } \\
\text { English } \\
\end{array}$ & 25 & 23 years \\
\hline 21 & Australia & Australia & English & Croatian & $\begin{array}{l}\text { Bosnian, } \\
\text { Croatian, } \\
\text { English }\end{array}$ & $\begin{array}{l}\text { Born in } \\
\text { Aust. }\end{array}$ & 15 years \\
\hline 22 & Croatia & $\begin{array}{l}\text { Croatia, Germany, } \\
\text { Croatia }\end{array}$ & Croatian & German & $\begin{array}{l}\text { Bosnian, } \\
\text { Croatian, } \\
\text { German } \\
\end{array}$ & $\begin{array}{l}\text { Returned } \\
\text { to Croatia }\end{array}$ & 20 years \\
\hline
\end{tabular}

Table 3. Demographic features of informants with two accreditations

\begin{tabular}{|c|c|c|c|c|c|c|c|}
\hline No. & $\begin{array}{l}\text { Country of } \\
\text { birth }\end{array}$ & $\begin{array}{l}\text { Countries } \\
\text { resided in }\end{array}$ & $\begin{array}{l}\text { Native } \\
\text { speaker of }\end{array}$ & $\begin{array}{l}\text { Near-native } \\
\text { speaker of }\end{array}$ & $\begin{array}{l}\text { Accreditation } \\
\text { from \& into }\end{array}$ & $\begin{array}{l}\text { Age at } \\
\text { arrival in } \\
\text { Aust. }\end{array}$ & $\begin{array}{l}\text { Length } \\
\text { of time } \\
\text { worked } \\
\text { as trsltr. }\end{array}$ \\
\hline 23 & Croatia & $\begin{array}{l}\text { Croatia, Bosnia- } \\
\text { Herzegovina, } \\
\text { Canada, USA }\end{array}$ & $\begin{array}{l}\text { Bosnian, } \\
\text { Croatian, } \\
\text { Serbian }\end{array}$ & English & $\begin{array}{l}\text { Bosnian, } \\
\text { Croatian, } \\
\text { Serbian, } \\
\text { English }\end{array}$ & 17 & 20 \\
\hline 24 & Australia & Australia, UK & English & $\begin{array}{l}\text { Bosnian, } \\
\text { Croatian, } \\
\text { Serbian, }\end{array}$ & $\begin{array}{l}\text { Bosnian, } \\
\text { Croatian, } \\
\text { Serbian, } \\
\text { English }\end{array}$ & $\begin{array}{l}\text { Born in } \\
\text { Aust. }\end{array}$ & 8 years \\
\hline 25 & Croatia & $\begin{array}{l}\text { Croatia, } \\
\text { Australia }\end{array}$ & Croatian & $\begin{array}{l}\text { Bosnian, } \\
\text { Serbian, } \\
\text { English }\end{array}$ & $\begin{array}{l}\text { Bosnian, } \\
\text { Croatian, } \\
\text { Serbian, } \\
\text { English } \\
\end{array}$ & 24 & 20 years \\
\hline 26 & Serbia & $\begin{array}{l}\text { Serbia, Bosnia- } \\
\text { Herzegovina, } \\
\text { Australia }\end{array}$ & Hungarian & $\begin{array}{l}\text { Bosnian, } \\
\text { Croatian, } \\
\text { Serbian, } \\
\text { English }\end{array}$ & $\begin{array}{l}\text { Bosnian, } \\
\text { Croatian, } \\
\text { Serbian, } \\
\text { English }\end{array}$ & 37 & 19 years \\
\hline 27 & Croatia & Croatia & Croatian & $\begin{array}{l}\text { Bosnian, } \\
\text { Serbian, } \\
\text { English, } \\
\text { German, }\end{array}$ & $\begin{array}{l}\text { Bosnian, } \\
\text { Croatian, } \\
\text { Serbian, } \\
\text { English, } \\
\text { German }\end{array}$ & $\begin{array}{l}\text { Still lives } \\
\text { in Croatia }\end{array}$ & 15 years \\
\hline 28 & Croatia & Croatia & Croatian & $\begin{array}{l}\text { Bosnian, } \\
\text { Serbian, } \\
\text { English }\end{array}$ & $\begin{array}{l}\text { Bosnian, } \\
\text { Croatian, } \\
\text { Serbian, } \\
\text { English }\end{array}$ & $\begin{array}{l}\text { Still lives } \\
\text { in Croatia }\end{array}$ & 20 years \\
\hline
\end{tabular}

Table 4. Demographic features of informants with three accreditations 
group of the sample. (The term 'accreditation' is an Australia-based term, but is used here as a hypernym to refer to formal recognition of inter-lingual transfer skills whether through accreditation or certification testing, or through a university qualification.) Those who selected two languages have been allocated to the 'double accreditation' group and so on (see Tables 2, 3 and 4 below). The Croatia- and Serbia-based practitioners generally translate into their A-language. However, as translators of smaller languages well know, the Croatia- and Serbia-based translators often consider and accept assignments into their B-language, and all of them identify themselves as bidirectional translators. Only one informant stated his/her inability to answer questions about translation into the B-language.

Tables 2, 3 and 4 above show that single-accreditation informants make up the majority of informants - seventeen while there are five informants with two and six informants with accreditations in three languages. The average length of time practising as a translator is seventeen years for translators with one accreditation, twenty-one years for those with two accreditations and seventeen years for those with three accreditations. Amongst those with dual or triple accreditation there is only limited evidence that residence in multiple countries could be a likely explanation for their dual or multiple accreditations. Further, only two of the six informants with three accreditations resided in Bosnia-Herzegovina, the only country in former Yugoslavia in which all three languages are official languages of a successor state. Instead, informants with multiple accreditations appear to have multiple accreditations due to their own (i.e. personal) efforts to acquire proficiency in two or three varieties. Table 5 below collates the data to show more clearly the presence of each language and informants' relationship to it.

\begin{tabular}{llll}
\hline & Native speaker & Near-native speaker & Accreditation \\
\hline Bosnian & 5 & 9 & 13 \\
\hline Croatian & 12 & 9 & 17 \\
\hline Serbian & 9 & 10 & 15 \\
\hline English & 6 & 19 & 25 \\
\hline German & 1 & 4 & 4 \\
\hline Macedonian & 2 & 0 & 2 \\
\hline Hungarian & 1 & 0 & 1 \\
\hline French & 1 & 0 & 1 \\
\hline
\end{tabular}

Table 5. Combined totals of proficiencies and accreditations according to language.

Table 5 above shows that the single most common native language listed is Croatian with twelve informants and this language, after English, claims the largest number of accreditations - seventeen. Five informants state they have two native languages, and two claim they have three. On average, each informants claims near-native proficiency in two languages further to their native one/s. In section 5 below, quantitative information is presented in tables which contain a break-up of informants and the number of accreditations that they possess. Totals equal the total number of informants $(=28)$ except in instances where multiple responses were allowed (Tables 8, 18 and 19). The informant number and his/her accredited language/s are presented after each quote from an informant. 


\section{Data and discussion}

This paper contains mostly quantitative data provided in raw numbers that relate to selections of responses from informants. This data is presented in tables each of which relate to one of the questions contained in the questionnaire. There are also solicited and unsolicited comments from informants which add to the picture provided by the quantitative data. Informant number and accredited languages are presented after quotes from informants. Data presented in this section is only briefly contextualised with the theoretical premises presented in section 2 above and the linguistic and T\&I features presented in section 3 above. Section 6 contains a fuller interpretation of the data and commentary on the professional practices and strategies of particular groups of translators.

A basic piece of information that is provided to translators in all settings is the language combination for which they are being employed. Table 6 below presents responses to a scenario in which a translator, after initial contact with the relevant party, establishes that the text is in a language different from the one for which the translation assignment had been requested.

\begin{tabular}{lllll}
\hline & $\begin{array}{l}\text { One } \\
\text { accredit. }\end{array}$ & $\begin{array}{l}\text { Two } \\
\text { accredit. }\end{array}$ & $\begin{array}{l}\text { Three } \\
\text { accredit. }\end{array}$ & Total \\
\hline $\begin{array}{l}\text { Check with the client that they } \\
\text { know which language it is in. }\end{array}$ & 10 & 2 & 3 & 15 \\
\hline Do nothing and translate as normal. & 3 & 1 & 2 & 6 \\
\hline Other & 4 & 1 & 1 & 6 \\
\hline No answer & 0 & 1 & 0 & 1 \\
\hline
\end{tabular}

Table 6. You have accepted a translation job, but when you receive it and look at the language you realise that the language is different from the language for which you had accepted the job. What do you do?

Table 6 above shows that most translators firstly check with the client. One informant provides the following information:

(1) If working for an agency I inform the agency that the language in actual fact is not Croatian, if that is the case, and then leave it up to them whether they want to proceed. Especially if the document is older, the official language was then Serbo-Croatian no matter which republic, and personally I have no problem with translating that, except if the alphabet is Cyrillic which I find harder and usually decline. (Inf. 21. Bos.+Cro.)

Relatively few informants commence with translation without asking further questions. Another informant makes a related comment based on the alphabet of the source text:

(2) If it is an emergency and it is a simple text, then yes, as I am proficient in Serbian and the Cyrillic alphabet (Inf. 12. Cro.)

\begin{tabular}{lllll}
\hline & $\begin{array}{l}\text { One } \\
\text { accredit. }\end{array}$ & $\begin{array}{l}\text { Two } \\
\text { accredit. }\end{array}$ & $\begin{array}{l}\text { Three } \\
\text { accredit. }\end{array}$ & Overall \\
\hline Yes & 3 & 2 & 2 & 7 \\
\hline No & 14 & 2 & 2 & 18 \\
\hline No answer & 0 & 1 & 2 & 3 \\
\hline
\end{tabular}

Table 7: Have you ever, through whichever circumstances, translated for a client in a language without accreditation or a credential in that language? 
Table 7 above shows that only one quarter (seven) of the informants have knowingly found themselves in situations where they have translated for a client in a language that they do not have accreditation for. Surprisingly, those with multiple accreditations report this more so than those with only one. Comments from many informants indicated that urgency and a lack of other available translators accounted for them taking on jobs in other languages. Others mentioned that this is a practice that agencies or other intermediary organisations often pursue. The following comments are reported by informants who answered 'yes' or who gave no answer.

(3) Yes, in special circumstances such as identifying evidence. (Inf. 20. Bos.+Cro.)

(4) If accreditation is not required for that specific job and if I feel confident that I could do it well. (Inf. 8. Cro.)

Many report that they are reluctant to use their official stamps or even charge a fee:

(5) Only informally and not in an official capacity for a fee. (Inf. 10. Ser.)

(6) I would INFORMALLY translate to or from Bosnian and Croatian if asked, but would never stamp the work or accept money for it. (Inf. 7. Ser. Original emphasis)

And one is clear that such a case would be a favour, rather than a paid assignment:

(7) I did translate some papers from German, but not documents. I have a BA degree in German, so I felt proficient enough. It was to help someone out who couldn't afford paying someone for it. (Inf. 26. Bos.+ Cro.+ Ser.)

A Europe-based practitioner states that in the global market, a formal credential may be of little importance:

(8) There are so many constellations of factors - with EU and North American clients - where accreditation is secondary or even irrelevant absolutely. (Inf. 2 Cro.)

Table 8 below shows the responses of ten informants to five accounts presented to them. (Multiple responses were permitted.)

\begin{tabular}{lllll}
\hline & $\begin{array}{l}\text { One } \\
\text { accredit. }\end{array}$ & $\begin{array}{l}\text { Two } \\
\text { accredit. }\end{array}$ & $\begin{array}{l}\text { Three } \\
\text { accredit. }\end{array}$ & Total \\
\hline $\begin{array}{l}\text { It is not ethical to accept work } \\
\text { for a language in which you } \\
\text { do not have accreditation }\end{array}$ & 7 & 3 & 3 & 13 \\
\hline $\begin{array}{l}\text { I do not believe that I can } \\
\text { adequately translate from or } \\
\text { into other languages. }\end{array}$ & 6 & 0 & 2 & 8 \\
\hline $\begin{array}{l}\text { Agencies will not consider me } \\
\text { professional. }\end{array}$ & 1 & 2 & 1 & 4 \\
\hline $\begin{array}{l}\text { I believe that clients or others } \\
\text { may not accept me as their } \\
\text { translator. }\end{array}$ & 3 & 0 & 0 & 3 \\
\hline
\end{tabular}

Table 8. Which responses do you agree with if you do not believe that it is good to work in languages in which you do not have accreditation or a credential? 
Table 8 shows that nearly half of the informants who decline work in languages for which they do not have accreditation do so on ethical grounds; a quarter select their incapacity to translate competently. Only a small number list lack of acceptance from clients as a reason. No informant selects a response which identifies the differences between the three languages as grounds for refusal. One informant relates her approach in the following way:

(9) I am accredited as a professional translator Croatian into English and I am reluctant to translate anything not strictly Croatian if I have to certify it, not because I believe I may not have done a good job but because of the certification - but have done so and have not had any adverse repercussions, after consulting the client/agency. (Inf. 12. Cro.)

As stated above in section 2, a number of terms were in official use in SFRY, the most widespread in three republics was 'Serbo-Croatian'. Other terms such as 'Bosnian-Croatian-Serbian' have some currency in some Western European countries. 'Montenegrin' is one of the official languages of Montenegro, along with 'Serbian'. Montenegro's small population (approx. 750,000 inhabitants, only half of whom designate their mother tongue as 'Montenegrin') means that this language is rarely specified as a language for which translation services are required. Tables 9 to 16 below list informants' responses to hypothetical requests for them to translate from and into varieties that have such designations. The last designation 'Yugoslav', is an inaccurate term used sometimes by outsiders who, by analogy to the name of the state, used its adjectival form as the name of the language of SFRY.

\begin{tabular}{lllll}
\hline & One accredit. & Two accredit. & Three accredit. & Total \\
\hline Yes & 7 & 3 & 5 & 15 \\
\hline Possibly & 6 & 1 & 1 & 8 \\
\hline No & 4 & 1 & 0 & 5 \\
\hline
\end{tabular}

Table 9. A client wants a translator for work from 'Serbo-Croatian' into English. Would you accept this request?

\begin{tabular}{lllll}
\hline & One accredit. & Two accredit. & Three accredit. & Total \\
\hline Yes & 6 & 2 & 5 & 13 \\
\hline Possibly & 4 & 2 & 1 & 7 \\
\hline No & 6 & 1 & 0 & 7 \\
\hline No answer & 1 & & & 1 \\
\hline
\end{tabular}

Table 10. A client wants a translator for work from English 'into Serbo-Croatian'. Would you accept this request?

\begin{tabular}{lllll}
\hline & One accredit. & Two accredit. & Three accredit. & Total \\
\hline Yes & 8 & 0 & 4 & 12 \\
\hline Possibly & 3 & 1 & 1 & 5 \\
\hline No & 6 & 4 & 1 & 11 \\
\hline
\end{tabular}

Table 11. A client wants a translator for work from 'Bosnian-Croatian-Serbian' into English. Would you accept this request? 


\begin{tabular}{lllll}
\hline & One accredit. & Two accredit. & Three accredit. & Total \\
\hline Yes & 6 & 0 & 1 & 7 \\
\hline Possibly & 3 & 1 & 3 & 7 \\
\hline No & 8 & 4 & 2 & 14 \\
\hline
\end{tabular}

Table 12. A client wants a translator for work from English into 'Bosnian-CroatianSerbian'. Would you accept this request?

\begin{tabular}{lllll}
\hline & One accredit. & Two accredit. & Three accredit. & Total \\
\hline Yes & 7 & 1 & 3 & 11 \\
\hline Possibly & 2 & 0 & 2 & 4 \\
\hline No & 8 & 4 & 1 & 13 \\
\hline
\end{tabular}

Table 13. A client wants a translator for work from 'Montenegrin' into English. Would you accept this request?

\begin{tabular}{lllll}
\hline & One accredit. & Two accredit. & Three accredit. & Total \\
\hline Yes & 4 & 0 & 0 & 4 \\
\hline Possibly & 4 & 0 & 1 & 5 \\
\hline No & 9 & 5 & 5 & 19 \\
\hline
\end{tabular}

Table 14. A client wants a translator for work from English into 'Montenegrin'. Would you accept this request?

\begin{tabular}{lllll}
\hline & One accredit. & Two accredit. & Three accredit. & Total \\
\hline Yes & 5 & 1 & 3 & 9 \\
\hline Possibly & 5 & 3 & 2 & 10 \\
\hline No & 7 & 1 & 1 & 9 \\
\hline
\end{tabular}

Table 15. A client wants a translator for work from 'Yugoslav' into English. Would you accept this request?

\begin{tabular}{lllll}
\hline & One accredit. & Two accredit. & Three accredit. & Total \\
\hline Yes & 3 & 1 & 0 & 4 \\
\hline Possibly & 5 & 0 & 2 & 7 \\
\hline No & 9 & 4 & 4 & 17 \\
\hline
\end{tabular}

Table 16. A client wants a translator for work from English into 'Yugoslav'. Would you accept this request?

Tables 9 to 16 show informants' responses to translation requests from and into the varieties 'Serbo-Croatian', 'Bosnian-Croatian-Serbian', 'Montenegrin' and 'Yugoslav'. Overall, positive responses for all language varieties and for all groups of informants are higher for translation from these varieties than into them. Informants are more amenable to accepting such requests where passive skills rather than active use of these varieties are requested. Generally, informants with three accreditations are more likely to accept requests than informants with two accreditations who are more likely to accept requests than informants with one accreditation. However, there is some variation and the small numbers of informants with multiple accreditations restrict comparability. Of all four designations, 'SerboCroatian', as the major official term used in SFRY, is accepted by around half of the informants. Affirmative responses to requests for the other codes peak at $47 \%$ (from 'Bosnian-Croatian-Serbian') and drop to $11 \%$ (into 
'Yugoslav'). The large number of 'possibly' responses relates largely to further information being provided by the client (cf. Table 6 above). One informant states:

(10) I very often answered 'Possibly', as the decision to proceed depends on negotiations with the clients/agencies. (Inf. 20. Cro.+Bos.)

As stated, informants are more likely to translate from rather than into these varieties. One informant identifies this distinction as grounds for accepting and declining work:

(11) I consider BCMS [Bosnian, Croatian, Montenegrin, Serbian] to be one language and, with due respect for the many differences in detail, I - and most of my clients - don't think this is an issue. Particularly seeing as I translate FROM and not into BCMS. (Inf. 2. Cro. Original emphasis, square brackets mine.)

Table 7 above showed that around two-thirds of informants do not accept requests to work in languages for which they do not have accreditation. At the same time, nine of the twenty-eight informants have multiple accreditations. Requests made to practitioners to work in languages in which they are not accredited may motivate some to seek multiple accreditations, with commensurate increases in the possibility of further income. Table 17 below records informants' responses to a question on this issue:

\begin{tabular}{lllll}
\hline & $\begin{array}{l}\text { One } \\
\text { accredit. }\end{array}$ & $\begin{array}{l}\text { Two } \\
\text { accredit. }\end{array}$ & $\begin{array}{l}\text { Three } \\
\text { accredit. }\end{array}$ & Total \\
\hline Yes & 5 & 0 & 2 & 7 \\
\hline No & 1 & 1 & 2 & 4 \\
\hline Perhaps & 11 & 4 & 2 & 17 \\
\hline
\end{tabular}

Table 17: Do you think the amount of work available to translators in each language motivates some translators to gain multiple accreditations and to take on work for other languages?

The responses from informants above are mixed. The desire for further income is identified by nearly a quarter of informants as a factor that motivates practitioners to seek multiple accreditations while a further $60 \%$ consider this possible. On the one hand, informants with three accreditations know whether multiple accreditations provide them with further work and one third respond affirmatively. Most of the informants with two accreditations are less sure, while a small number of informants with one accreditation suspect that multiple accreditations do provide more work while the majority from this group consider this only a possibility.

As practising translators, informants rely on bilingual resources in their work and in their continuing professional development. None of the informants' languages are major world languages and the repertoire of available bi- or mono-lingual resources, in the informants' languages is limited. Due to the limited supply of materials, some practitioners with single accreditation may use materials from other languages. Informants with multiple accreditations would be very likely to do this. Table 18 below documents informants' conventions; multiple responses are allowed which results in a total higher than twenty-eight. The responses show that most informants from all groups draw on resources from more than one language informants with one accreditation do so through choice and informants with multiple accreditations do so because their professional duties require this of 


\begin{tabular}{lllll}
\hline & $\begin{array}{l}\text { One } \\
\text { accredit. }\end{array}$ & $\begin{array}{l}\text { Two } \\
\text { accredit. }\end{array}$ & $\begin{array}{l}\text { Three } \\
\text { accredit. }\end{array}$ & Total \\
\hline $\begin{array}{l}\text { Yes. I have multiple accreditations and } \\
\text { this is part of my professional } \\
\text { development. }\end{array}$ & 3 & 5 & 5 & 13 \\
\hline $\begin{array}{l}\text { Yes. I have accreditation for one language } \\
\text { only but like to draw on resources from } \\
\text { other languages. }\end{array}$ & 10 & 0 & 0 & 10 \\
\hline $\begin{array}{l}\text { Yes, because it is difficult to have access } \\
\text { to a lot of specialised material in various } \\
\text { fields for one language only. }\end{array}$ & 6 & 1 & 2 & 9 \\
\hline $\begin{array}{l}\text { No. It is not good to use materials from } \\
\text { other languages as these are not relevant } \\
\text { to my performance as a translator in my } \\
\text { language. }\end{array}$ & 3 & 0 & 0 & 3 \\
\hline $\begin{array}{l}\text { No. I tend not to need support materials } \\
\text { from any language. }\end{array}$ & 1 & 0 & 1 & 2 \\
\hline
\end{tabular}

Table 18. Do you use manuals, lexica, dictionaries, glossaries from a variety of languages to keep up your language skills?

\begin{tabular}{lllll}
\hline & $\begin{array}{l}\text { One } \\
\text { accredit. }\end{array}$ & $\begin{array}{l}\text { Two } \\
\text { accredit. }\end{array}$ & $\begin{array}{l}\text { Three } \\
\text { accredit. }\end{array}$ & Total \\
\hline Yes. Clients & 6 & 3 & 3 & 12 \\
\hline Yes. Agencies & 5 & 3 & 2 & 10 \\
\hline $\begin{array}{l}\text { Yes. Fellow } \\
\text { translators }\end{array}$ & 5 & 0 & 3 & 8 \\
\hline No & 6 & 0 & 3 & 9 \\
\hline
\end{tabular}

Table 19. Have you ever come across agencies, clients or fellow translators who disregard or who question the distinctness of Bosnian, Croatian and Serbian as separate languages?

them. A third of informants agree that a lack of materials in each language motivates them to do this and relatively few informants reject materials from other languages as an irrelevant or undesirable practice.

Table 19 above elicits responses to a question which can relate to the actual behaviour of others as well as to their views. (Multiple responses were counted for this question as well.) Informants' behaviour can be measured in the examples of informants who take on work in other languages (without accreditation) because they believe that they are able to perform as an translator for that language (see above Table 7) and in the examples of agencies who may assign translators work in other languages. Table 19 above shows that two-thirds of informants have experienced others who disregard or question the distinctness of the three languages, most commonly from clients and least commonly from fellow translators. Some informants report that this can be accidental, and caused by the mismatch between country of birth and language spoken:

(12) I often get translations marked as Serbian, which are actually Croatian, because it is a Serbian person coming from Croatia, who has Croatian documents, but they are known as Serbians. I then just let the agency know the correct language and I do it anyhow, because I am accredited in all of these languages. (Inf. 26. Bos.+Cro.+Ser.) 
(13) Clients often list something else (such as ethnicity rather than language spoken or used in the country of origin), but once they understand the language listed should match the country the document was issued in, they agree to have that language listed even though their personal preference might be something else. Due to all the confusion in the early '90s, when dealing with personal documents from overseas, the Australian Government decided to disregard the nominated language as specified by the client and take the country of issue as the official language to be listed, allocating translators accordingly. (Inf. 20. Bos. + Cro.)

(14) Sometimes I have received birth certificates from the Republika Srpska, that were on a Croatian form, but filled out in Serbian, in Cyrillic letters, so I did write in my certification that it is a certificate where the form is Croatian and the contents is Serbian, and I put both my Serbian and Croatian NAATI stamps on it. It never came back. (Inf. 18. Cro.+Ser.)

One informant expresses the view that he considers all the languages to be one:

(15) I find it perfectly legitimate for people to call the language by their own ethnic label. I consider BCMS to be *objectively* one language because the codes are mutually comprehensible to a very high degree and have $95 \%($ ?) the same grammar and syntax, $80 \%$ (?) the same vocabulary, etc. (Inf. 2. Cro. Original punctuation.)

At the same time, comment (15) comes from the informant who provided comment (11) which reports that this practitioner only translates from each of the languages rather than into them. Translation into the different codes alerts practitioners to the differences that pertain to each of the three standards:

(16) Although the three languages are not hugely different, they are recognised as separate languages and in order for translators (and interpreters) to accept paid work in a particular language they should be accredited in that language. This is important in order to maintain credibility and professionalism. Having said that I don't mind assisting people when needed (usually friends or neighbours), either with translations or interpreting, but I would not charge a fee for this. (Inf. 10. Ser. Original round brackets.)

Another practitioner, from the 'smallest' of the three languages, complains that a lack of distinction is detrimental to work opportunities and to the general profile of the ethnic group:

(17) One of the biggest problems that Bosnian translators face is agencies' grouping Bosnian together with related languages such as Serbian and Croatian. There have been a lot of cases where agencies suggest that the client should accept a Serbian or Croatian translator rather than a Bosnian one. Clients do it themselves because they believe that they'll find a translator more quickly and don't really care who the translator is. I really think that clients should insist on a translator for their language for the simple reason that it ensures the maintenance of their own identity. (Inf. 4. Bos.)

\section{Findings and conclusion}

This sample is small, and as stated in section 4 above, cannot be considered representative of all translators for the Bosnian, Croatian and Serbian languages in Australia or elsewhere. The detailed responses above, however, 
allow for some generalisations to be made. In the first place, eight (29\%) of the twenty-eight informants were not born in Bosnia-Herzegovina, Croatia or Serbia, but the likely ethnic origin of the overwhelming majority of translators is Bosnian, Croatian or Serbian. Multiple places of residence are not a factor which influences informants' number of accreditations, nor the number of years that they have been practising. Neither residence in multiple republics nor length of service as a translator motivates practitioners to seek accreditation for all three languages.

When they encounter texts in a language different from that for which an assignment had been accepted, most informants firstly check with clients. Two-thirds of the informants are reluctant to accept assignments for languages for which they do not have accreditation, firstly on ethical grounds, and secondly due to doubts of competence in the language variety sought. About half of the informants are receptive to assignments that request translation from or into an old and now disused designation, 'SerboCroatian'. Narrow to large majorities reject requests for translation from or into codes labelled 'Bosnian-Croatian-Serbian', 'Montenegrin' and 'Yugoslav' respectively. The responses in relation to broader work opportunities and therefore increased income as an incentive for some practitioners to seek multiple accreditations are mixed and inconclusive. This is perhaps surprising given the significant number of practitioners who list multiple working languages, even where they are genealogically unrelated. Over $80 \%$ of informants use resources from more than one language, either through necessity as a practitioner with multiple accreditations or through lack of availability of a large number of resources in one language only. Informants also report that many with whom they have professional contact, in particular clients and agencies, sometimes disregard the differences between the three languages. It is hard to gauge whether these responses are based on a general view that the languages are the same, or whether this is a consequence of some clients' and agencies' belief that any translator that works in any of the three languages can service any client from one of the three languages.

Informants with multiple accreditations are generally more likely to accept requests for assignments with a non-standard designation. However, the differences between the informants with multiple (two or three) accreditations and those with one are in some areas substantial, in others negligible. There are few differences that can be ascertained between Australia- and Europe-based translators, although the small size of both samples limits the ability to provide conclusive comparisons.

Responses from the informants, in general and according to the number of accreditations that they have, suggest that informants may view the three languages in particular ways. These have consequences firstly on whether and how they accommodate to other varieties and secondly, how this otherwise manifests itself in their professional conduct. I posit that there are up to five outlooks on the languages and I group the numbers of informants within each group according to the statistical and qualitative data provided by each informant:

1. Translators who consider the three languages separate and distinct and who view translation outside their 'own' language or outside the language for which they have accreditation to be non-felicitous and/or problematic ethically. These practitioners almost always have accreditation in one language only, generally decline requests for assignments for other languages, accept them only in exceptional circumstances, and work in their 'own' language only. (Informants: 
$3,4,5,7,8,11,12,15,16$ and $17=$ total 10 . Seven of these informants are Australia-based while the remaining three are in Europe. )

2. Translators who consider the three languages separate and distinct but who consider translation for languages outside their 'own' and for which they may not have accreditation where opportunities arise. Translation for 'other' languages is performed on an ad-hoc, impromptu or unpaid basis, or with payment where this is acceptable to other parties. These translators generally have accreditation in one language only and generally work in one language. (Informants: 1, 6, 10,14 and $21=$ total 5. Three are Australia-based; two are in Europe.)

3. Translators who consider the three languages separate and distinct and who have an active and native command of at least two, if not all three of the languages, therefore circumventing the need to accommodate across linguistic boundaries because they have multiple-group membership as co-native-speakers of all three languages. These translators are likely to have multiple accreditations and to work at the same level of expertise in each language community. Clients' questions of proficiency are responded to with information about their professional and linguistic credentials. (Informants: 9, 18, 19, 20, 22, 23, 25, 26, 27 and $28=$ total 10. Six are Australia-based; four are Europe-based.)

4. Translators who consider all three languages to be one language with different varieties. Some may have multiple accreditations, others may have accreditation in only one language. This latter group of translators hold a view that certified expertise in one variety enables them to practice in all varieties. Non-standard or disused designations of the languages are also accepted. Generally, this group of translators is open to translation from all language varieties and possibly into many different varieties. (Informants: 2, 13 and $24=$ total 3. All are born in Australia, while one is Europe-based.)

These posited outlooks are based on informants' responses, i.e. data were processed first which gave rise to these outlooks, rather than outlooks being posited first and the data were required to 'fit' them. The outlooks seek to generalise the differences between groups of informants on the basis of their general responses to acceptance of work in other languages, and accounts of the linguistic, professional and ethical features that guide their decisions. Some patterns are apparent: outlook (1) encompasses only single-accredited translators who have a delineated view of the languages with restricting consequences on acceptance of assignments - ten informants hold this view; outlook (2) views the languages as separate but translation in 'other' languages as an inter-actionally acceptable strategy in certain situations and with conditions applied to the verification and liability of the performed translation - five informants hold this view; outlook (3) is almost a double or triple native speaker view of the three languages and, unsurprisingly, is held by four of the five informants with two accreditations and five of the six informants with three accreditations; outlook (4) is held by three informants who downplay the distinctions or reject the separateness of the three languages and who believe that proficiency in one variety ensures this in all varieties. Translators in the Bosnian, Croatian and Serbian languages (mainly residing in Australia) now largely follow one of two paths: holding accreditation and working in one language only; holding multiple accreditations and accepting work in any of these languages. For both groups, 
acceptance of work outside accreditation is not common. With continuing separation between groups (notwithstanding cross-border contacts and globalisation) there is decreasing likelihood that T\&I practitioners can competently and professionally service linguistically similar but distinct groups. For them to do this, they now increasingly require proficiency in the distinct, codified standards and socio-cultural knowledge of the repositioned speech communities in the respective homelands and abroad.

\section{Notes}

1 'The National Accreditation Authority for Translators and Interpreters Ltd (NAATI) is the body responsible for setting and monitoring the standards for the translating and interpreting profession in Australia. It does this through its system of accreditation. NAATI accreditation is the only credential officially accepted by employers for the profession of translation and interpreting in Australia.' (NAATI 2011b).

${ }^{2}$ In the period 1971 to 1992 , when Bosnia-Herzegovina was a constituent republic of SFRY, the term 'Muslim' (Musliman) was used by authorities and by the group itself as an ethnic label for a group that had otherwise distinguished itself from others through its Islamic faith.

${ }^{3}$ Approval to contact potential informants and collect data was granted by the Standing Committee on Ethics in Research Involving Humans (SCERH), Monash University. Project Number 2007002093. 


\section{References}

American Translators Association (n.d.). Online directories. Retrieved October 19, 2012, from http://www.atanet.org/onlinedirectories/individuals.php

Association of Translators and Translators in Ontario. (n.d.). Online directories. Retrieved October 19, 2012, from http://search.atio.on.ca/search/index/1

Babić, S. (1990). Hrvatski jezik u političkom vrtlogu [The Croatian language in a political maelstrom]. Zagreb: Ante Pelivan

Badurina, L., Pranjković, I., \& Silić, J. (Eds.). (2009). Jezični varijeteti $i$ nacionalni identiteti. [Linguistic variants and national identities]. Zagreb: Disput.

BDÜ [Bundesverband der Dolmetscher und Übersetzer]. (2012). Suche nach Übersetzern/Dolmetschern.Retrieved October 19, 2012, from http://www.bdue.de/

Bugarski, R. (2002). Nova lica jezika. [The new faces of language.] Belgrade: Slovograf.

Bugarski, R., \& Hawkesworth, C. (Eds.) (2004). Language in the former Yugoslav lands. Bloomington: Slavica.

Constitution of Montenegro [Ustav Crne Gore] (20070. Retrieved October 19, 2012, from www.skupstina.me/cms/site_data/ustav/Ustav\%20Crne\%20Gore.pdf

Dragosavljevic, A. (2000). Language policies and academic responses: the Ekavian debate in Republika Srpska. Australian Slavic and East European Studies, 14(1-2), 1-27

Dragovic-Drouet, M. (2007). The practice of translation and translation during the conflicts in the former Yugoslavia (1991-1999). In M. Salama Carr (Ed.), Translating and translation conflict (pp.29-40). Amsterdam: Rodopi.

Draženović-Carrieri, M. (2002). BCS - A practical approach. In R. Lučić (Ed.), Lexical norm and national language. Lexicography and language policy in South Slavic languages after 1989 (pp.49-52). Munich: Otto Sagner.

Giles, H., Coupland, N., \& Coupland, J. (1991). Accommodation theory: Communication, context and consequence. In H. Giles, N. Coupland \& J. Coupland (Eds.), Contexts of accommodation: developments in applied sociolinguistics (pp.1-68). Cambridge: Cambridge University Press.

Glušica, R. (2009). Jezičke prilike u Crnoj Gori. [The linguistic situation in Montenegro ], In L. Badurina, I. Pranjković \& J. Silić (Eds.), Jezični varijeteti $i$ nacionalni identiteti. [Linguistic variants and national identities] (pp.137-146). Zagreb: Disput.

Greenberg, Robert (2004a). Language and Identity in the Balkans. Oxford: Oxford University Press.

Greenberg, R.(2004b). From Serbo-Croatian to Montenegrin? Politics of language in Montenegro. In R. Bugarski \& C. Hawkesworth (Eds.), Language in the former Yugoslav lands (pp.53-66). Bloomington: Slavica.

Gustavsson, S. (2009). Language standards and norms in 5-8/9 grade schoolbooks for Croatian, Serbian and Bosniac pupils in Bosnia and Herzegovina. In L. Badurina, I. Pranjković \& J. Silić (Eds.), Jezični varijeteti i nacionalni identiteti. [Linguistic variants and national identities] (pp.399-432). Zagreb: Disput. 
Halilović, S. (1998). Bosanski jezik. [The Bosnian language] Second Edition. Sarajevo: Baština.

ICTY. (2010). Decision on Zdravko Tolimir's request for transcripts in a language which he understands. Case No.: IT-05-88/2-T. Retrieved November 20, 2011, from icty.org/x/cases/tolimir/tdec/en/100827a.pdf

Jahić, D. (2000). Bosanski jezik u 100 pitanja i 100 odgovora. [The Bosnian language in 100 questions and 100 answers.] Zenica: Biblioteka Linguos.

Justizportal des Bundes und der Länder (n.d.) Dolmetscher/innen und Übersetzer/innen suchen (Gesamtbestand: 21976 Personen). Retrieved October 19, 2012, from http://www.justiz-dolmetscher.de/suche.jsp

Kalogjera, D. (2004). Serbo-Croatian into Croatian: fragment of a chronicle. In R. Bugarski, \& C Hawkesworth (Eds.), Language in the former Yugoslav lands (pp.85-104). Bloomington: Slavica.

Kloss, H. (1976). Abstandsprachen und Ausbausprachen. In J. Göschel (Ed.) Zur Theorie des Dialekts: Aufsätze aus 100 Jahren Forschung (pp.301322). Wiesbaden. Harrasowitz.

Kuhiwczak, P. (1999). Translation and language games in the Balkans. In G. Anderman \& R. Rogers (Eds.), Liber Amicorum for Peter Newmark. Word, Text, Translation (pp.217-224). Clevedon, UK: Multilingual Matters.

Love, N., \& Umberto, A. (2010). The native speaker and the mother tongue. Language Sciences, 32, 589-593.

Maštrović, T., \& and Machala, L. (2011). Međunarodno priznanje hrvatskoga jezika. [The international recognition of the Croatian language.] Zagreb: Nacionalna i sveučilišna knjižnica u Zagrebu.

Myers-Scotton, C. (1983). The negotiation of identities in conversation: A theory of markedness and code choice. International Journal of the Sociology of Language, 44, 114-136.

NAATI [National Accreditation Authority for Translators and Interpreters]. (2011a). NAATI Online Directory. Retrieved October 19, 2012, from https://www.naati.com.au/online/PDSearch/AdvancedSearch

NAATI [National Accreditation Authority for Translators and Interpreters]. (2011b). Why is NAATI accreditation important in Australia. Retrieved October 19, 2012, from http://www.naati.com.au/accreditation.html

Neweklowsky, G. (Ed.). (2003). Bosanski-Hrvatski-Srpski. BosnischKroatisch - Serbisch. Aktuelna pitanja jezika Bošnjaka, Hrvata, Srba i Crnogoraca. [Bosnian - Croatian - Serbian. Current questions on the languages of the Bosniaks, Croats, Serbs and Montenegrins] Vienna: Wiener Slawistischer Almanach. Sonderband 57.

Neweklowsky, G. (2004). Serbo-Croatian and its successors in Austria. In R. Bugarski \& C. Hawkesworth (Eds.), Language in the former Yugoslav lands (pp.243-250). Bloomington: Slavica.

Nikčević, V. (2009). Crnogorski interdijalektni/naddijalektni (koine) standardni jezik. [The Montenegrin interdialectal/supradialectal (koine) standard language] In L. Badurina, I. Pranjković \& J. Silić (Eds.), Jezični varijeteti i nacionalni identiteti. [Linguistic variants and national identities] (pp.147-168). Zagreb: Disput.

NRPSI [National Register of Public Service Interpreters]. (2011). Find an interpreter. Retrieved October 19, 2012, from http://www.nrpsi.co.uk/search.php

Okuka, M. (1998). Eine Sprache, viele Erben. Sprachpolitik als Nationalisierungsinstrument in Ex-Jugoslawien. Klagenfurt: Wieser.

Palić, I. (2009). Mogućnosti funkcioniranja triju standardnih jezika (bosanskoga, hrvatskoga i srpskoga) u Bosni i Hercegovini. [The 
possibilities of the functioning of three standard languages (Bosnian, Croatian and Serbian) in Bosnia-Hercegovina]. In L. Badurina, I. Pranjković \& J. Silić (Eds.), Jezični varijeteti i nacionalni identiteti. [Linguistic variants and national identities] (pp.111-124). Zagreb: Disput.

Popović, L. (2004). From standard Serbian through Serbo-Croatian to standard Serbian. In R. Bugarski \& C. Hawkesworth (Eds.), Language in the former Yugoslav lands (pp.25-40). Bloomington: Slavica.

Pupavac, V. (2006). Language rights in conflict and the denial of language as communication. The International Journal of Human Rights, 10(1), 61-78.

Pym, A. (2010). Exploring translation theories. London/New York: Routledge.

Radovanović, M. (2004). From Serbo-Croatian to Serbian: External and internal language developments. In R. Bugarski \& C. Hawkesworth (Eds.), Language in the former Yugoslav lands (pp.15-25). Bloomington: Slavica.

Schweda Nicholson, N. (2003). Translation at the International Criminal Tribunal for the former Yugoslavia: Linguistic and cultural challenges. In H. Tonkin \& M. Esposito Frank (Eds.), The Translator as Mediator of Cultures (pp.37-52). Amsterdam/Philadelphia: John Benjamins.

Tolimir-Hölzl, N. (2009). Bosnien und Herzegowina. Sprachliche Divergenz auf dem Prüfstand. Munich: Otto Sagner.

Universitas. (n.d.). Verzeichnis-Suche. Retrieved October 19, 2012, from http://www.universitas.org/de/service/uebersetzerinnen-unddolmetscherinnen/einfache-suche/

Vinay, J., \& Darbelnet, J. (1958/1972). Stylistique comparée du français et de l'anglais: method de traduction. Paris: Didier. 